\title{
筧尿用留貫カテーテルによる煩骨宿没骨折の整推固定
}

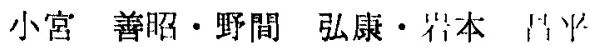

\section{Balloon technic for treatment of impacted fracture of the zygomatic bone}

\author{
Yoshiaki Komıуa - Hiroyasu Noma - Masahira Imamoto
}

はじめに

近年交通災害・労働災害の大型化に伴って，烦骨骨折 加增加している．頓骨は顔面の前外方に突出しているた め、ここに外力を受ける機会が多く，この骨を中心とし た骨折仕下頻骨についで多く見られる。

頼骨㤌，此較的強固な体部を中心として，4つの突起 走出し，前頭骨，蝶形骨，上頻骨ならびに側頭骨と接続 して. 眼営の外壁, 上頻洞上側壁などの棈成にす関与し ている．てたがって頓骨に外力が加わった場合には，煩 骨体の折れることは少なく，煩骨に接している顔面骨の ら占满造的に弱い部位が骨折するので，多くは宿没骨折 の型をとる。

䫅骨宿没骨折では，煩骨前頭释合部之煩骨弓が骨折離 断し，上頻洞の前外壁と腿窝下底が挫隇骨折して煩骨が 内下方に変位することが多いため, 眼球陥没, 複視, 眼富

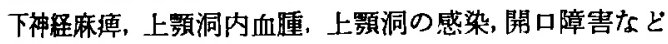
䠰林的に重大な合併症を伴らことが多い。かです，眼の 蹱害や，開口障害は変位した顂骨が解剖学的に正常な位 置にまで整復されないかきりり改善されないので，頼骨の 変位骨折你祭しては，適切な整復固定手術が必要である.

私達は新鮮な煩骨陥没骨折に対して, 導尿用留監カテ ーテルを用いる整復固定法を試みて，きわめて良好な結 果をあげている，ここにその代表例をあげ，本法の術式 について報告するととるに，適応の範囲について検討し てみた。

\section{症例}

患者 : 27歳，男性

初診: 昭和 46 年 2 月日日

既往歴：特記すべき疾患なし

現病歴：昭和46年 1 月曰日泥醉して転倒し，左側頝骨

東京粀科大学口腔外科学教室 (主任: 高椅 庄二郎 教授)

Department of Oral Surgery, Tokyo Dental Callege (Chief:

Prof. Shojiro Takahashi)

受付 绍和 47 年 9 月 4 日

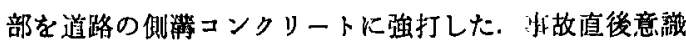
消失を生し，近医で応急処膡を受け，同年 2 月曰日開口 障害を主訴として来院した。

現症: 脳神経学的榆查および一般顿查には全く異常は 認められない。

左側煩骨部が宿没し，触部飞より左側外眼角部，眼窝 下縁ならびに煩骨弓中央部に骨折線の变位を示すステッ ブを触知する，眼瞼皮席拉よび眼睑，眼球結膜には强い 出血斑が見られる（写 1). 左側眼球は外上万人の運

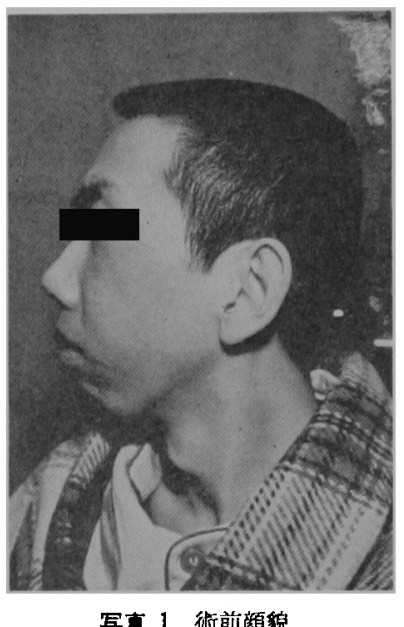

写真 1 術前顔貌

動が制限されており，この方向の視野では複視が認めら れる. また。眼窝下神経領域にははぼ完全な知覚麻㾝が 見られる。

中等度の笪運動障害があり，最大開口は $25 \mathrm{~mm}$ であ るが，咬合は不能で上下頻歯牙には約 $5 \mathrm{~mm}$ の間隙があ る. 下顎は右側に变位しているが上下顎の歯列には異常 は認められない。

X線所見では，煩骨前頭突起，頼骨弓，眼窝下底およ び上颗洞前壁に骨折線があり，頓骨が内下方に变位して いる像が見られる（写真 2，3，4，および図 1).

診断およひ姏置方針：顂骨が上賈洞内に陌没したタイ 


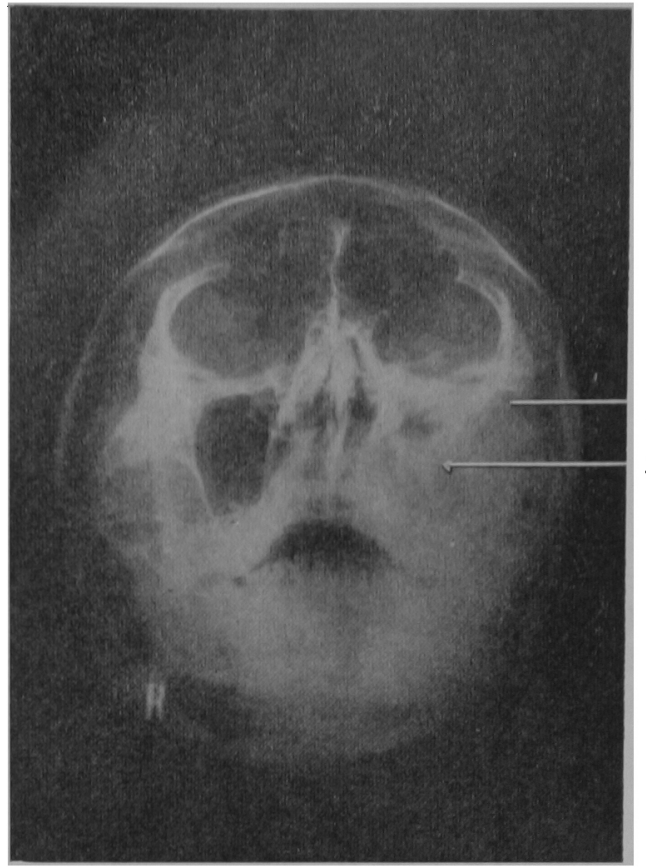

写索 2 術前X線像

a .上影洞内に所没した煩骨と煩骨下陵 b . 煩骨前頭突起の骨折線

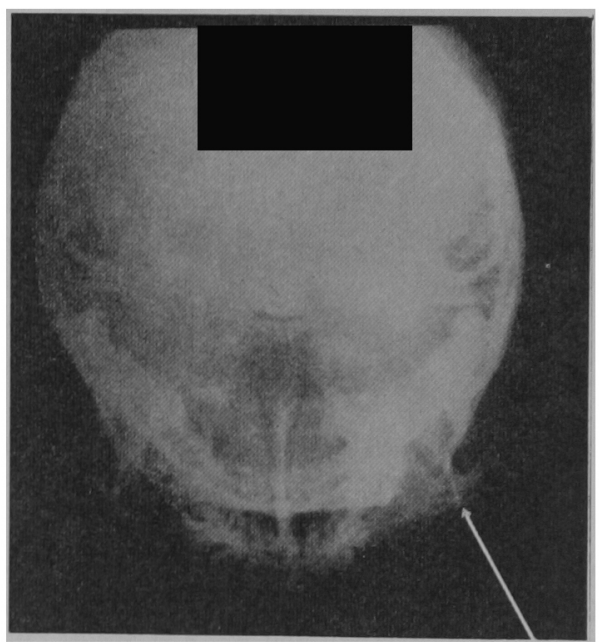

写事 3 術前 X線像

a

a、陥没した頼骨

プの新鮮骨折で，上額洞前壁，側壁が粉碎骨折している が，上顎骨には变位がなく，上顎洞の感染もないことか ら balloon method Kよる整復固定術が最適であると診 断した.

手術なよび経過：気管内㨉管による全身麻酔下に， $\underline{12-7}$ 部跟煩移行部を切開し, 眼窝下縁から煩骨体部ま

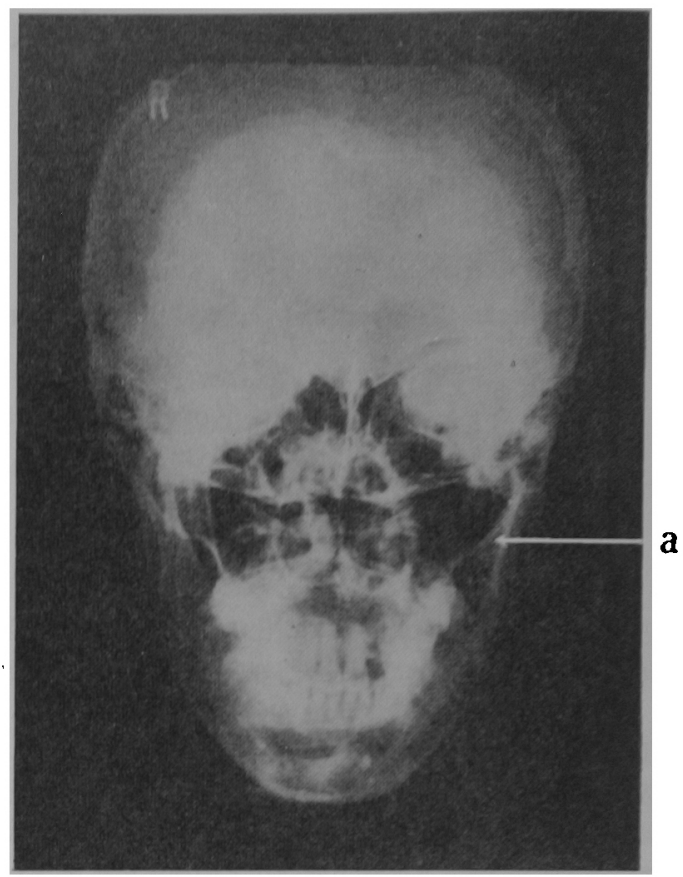

写兵 4 術前X棌像

a 、煩骨および㛲骨下陵は，上频洞内に陌没している. 上頻洞内には，血原による Radioopaque area が強い。

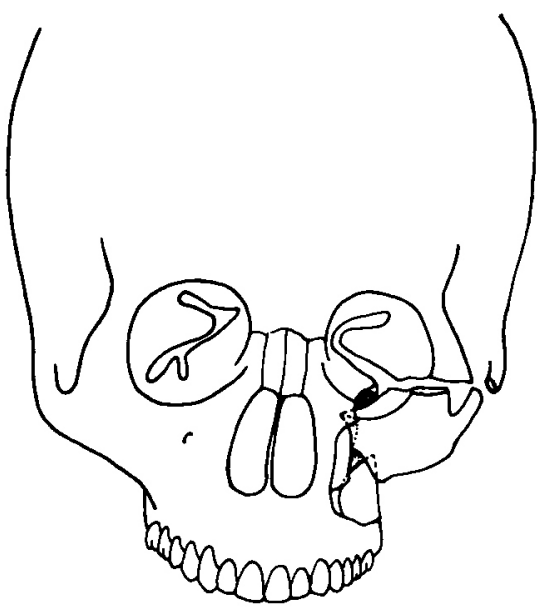

因 1 骨片变位を示す模式图

で骨膜を剥離し，骨折片の間隚から，上頻洞内の血曞を 吸引した（図 2).ついで下鼾道から受傷側の上頻洞へ 小孔を開け，ここから洞内に留直カテーテルを挿入した (図 3). 留置カテーテルは. 内径 $3 \mathrm{~mm}$, balloon の容量 30 45 ml のものを使用した. カテーテル挿入後，抗生 剂溶解生理食塩液で洞内を洗淮し，balloon の空気注入 ロから, $50 \mathrm{~m} l$ シリンジで空気を注入して balloon を䁗脹 


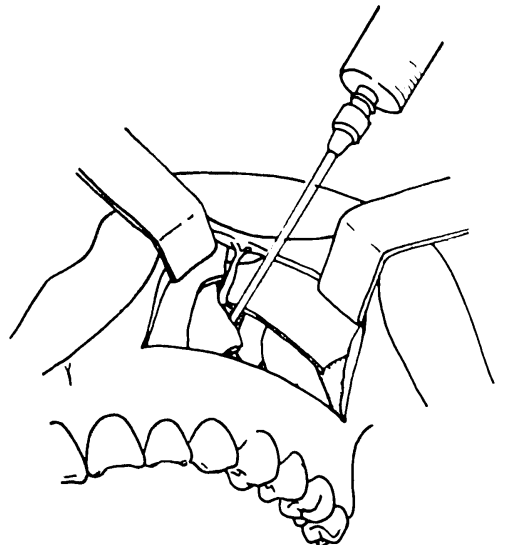

図 2 上顎洞内の血膒吸引

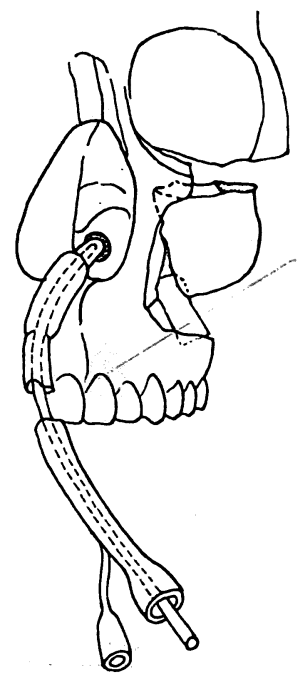

図 3 下奥道からの留膡カテーテル插入

させると宿没した頓骨が外前方に押し出された。この際， 骨膜起子を頓骨体の下方に当てて整復の補助とする（図 4). 口腔内から直視出来ない部位の整復状況は, 頓骨前 頭突起部，頓骨弓部の触診で知ることが出来る（図 5). なお，この症例では，眼骷下縁の骨折線部だけが， over reduction する傾向があったため, $0.3 \mathrm{~mm} 18: 8$ 鋼線 て簡単な骨縫合を行なった（図 6). 眼窩下縁. 䫅骨前 頍突起，頓骨弓部が完全に整復されたところで空気の注 入を中止し，先端を鈍にした歯科用探針で粉砕した骨片 をできるたけ整復した後，粘膜骨膜弁を旧位にもどし て䋖合閉鎖した．なお，咬合運動による咬筋の作用を軽 減するため顎間固定を行なった.

術後，12日間抗生物質の投与を行ない，感染を防止す ると共に、留置カテーテルから持続吸引を行ない, 術後 の浮腫の防止をはかった：また，上顎洞粘膜の血流栄養

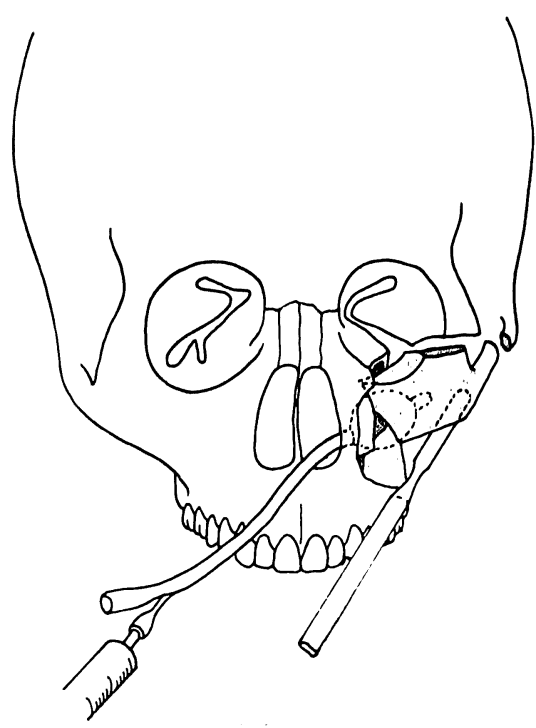

図 4 骨膜起子による骨片整復補助

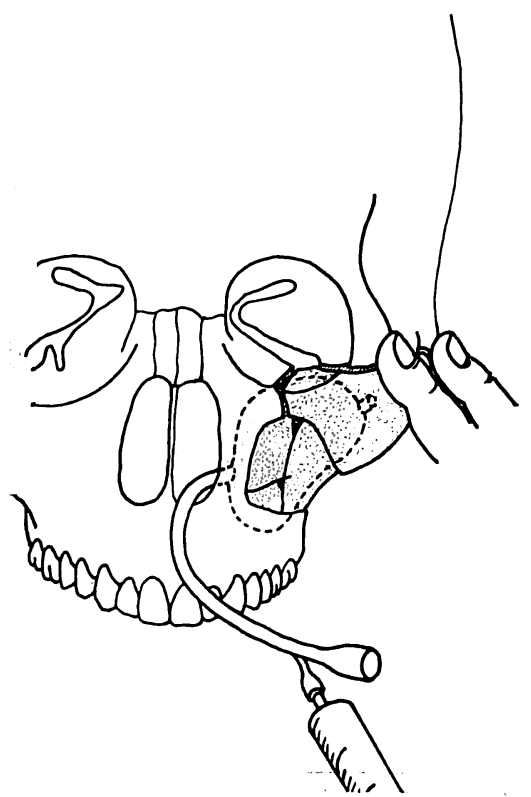

図 5 balloon 内への空気注入と触診による骨片整復補助

障害を軽減するために, 1 日 $5 \sim 6$ 回 balloon の空気を ぬきそのつど再注入した。

術後の経過はきわめて良好で, 患部の浮腫や疼痛は全 く見られなかった，術後 8 日で留置カテーテルを，1カ 月後に顎間固定を除去した. 写真 5 は術後 2 カ月目の顔 貌で，左右対称，術前に認められた複視，眼窝下神経麻 痺は完全に消失していた。 


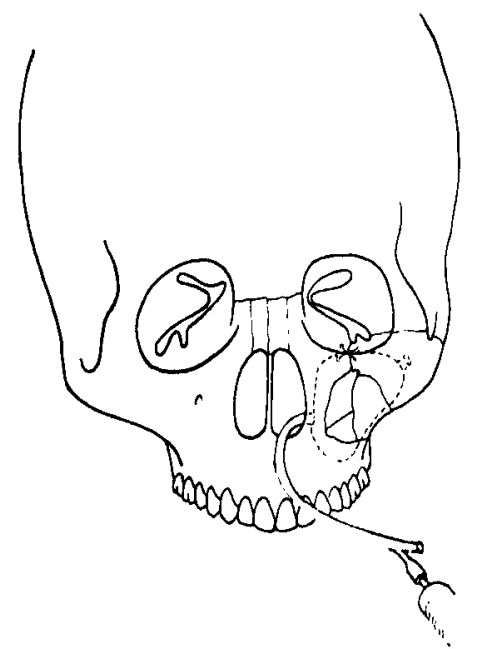

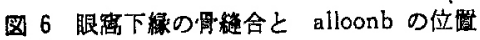

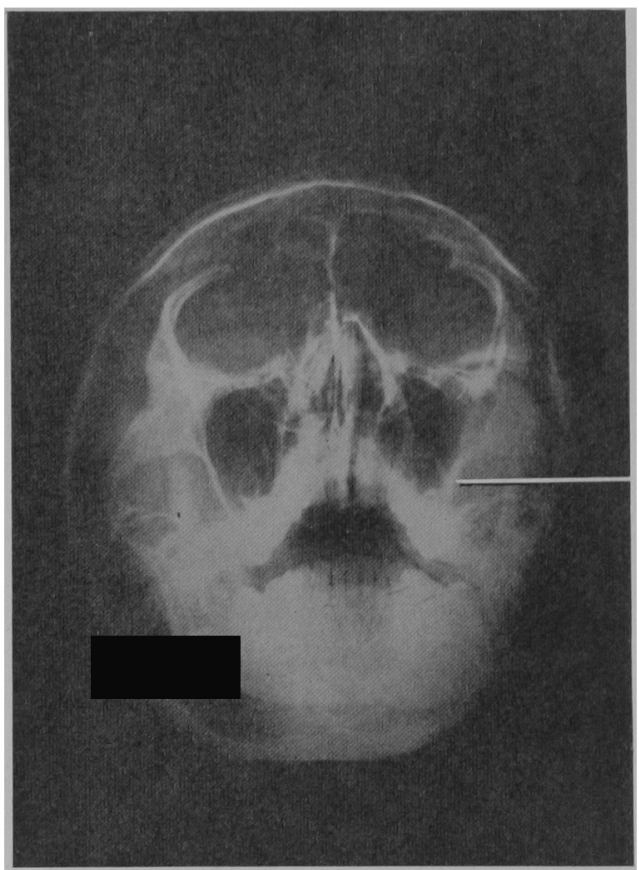

写真 6 衍後X線像

a 、頓骨は完全に整復されている

X線フィルムでは, 项骨は各部ともその解剖学的位膡 を保ち，留置カテーテル除去後の変位は全く認められな い(写真 6，7，および 8). また，術後，臨床的に，X 線像からも上類炎を䈝う所見は認められなかった。

$$
\text { 考察 }
$$

煩骨骨折の整復には種々の方法があるが，それぞれ一

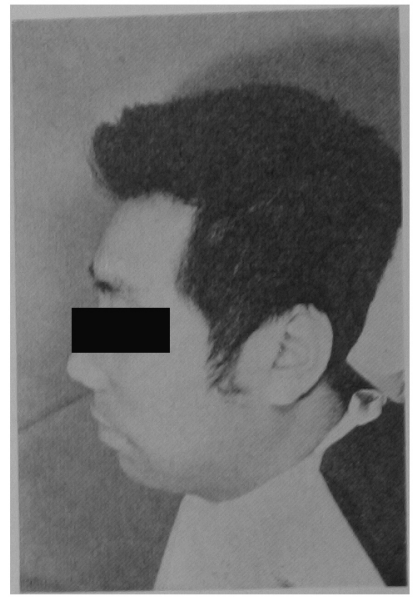

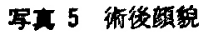

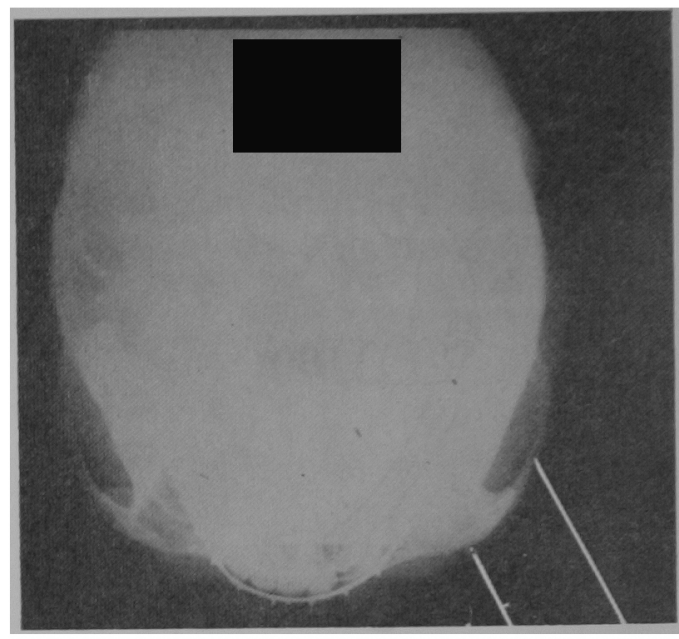

写本 7 術後X線像

煩骨体(a)，および煩骨弓(b)の骨折線は完全に擎传されて いる.

長一短があり，個々の症例に応じて，使いわけられるぺ きである、これらを大別すると次のような方法がある。

1. 口内法

2. 側頭経由法

3. head cap を用いる方法
a. 率引法
b. ピソを用いる方法

4. 上䫓洞経由法
a 、奥空経由
b 、犬歯㸗経由

5. 骨释合法

口内法は蒢䫅移行部を切開し，頝骨体を前外方に引き 出す方法で，頓骨弓，煩骨前頭綎合部の骨折に変位の少 


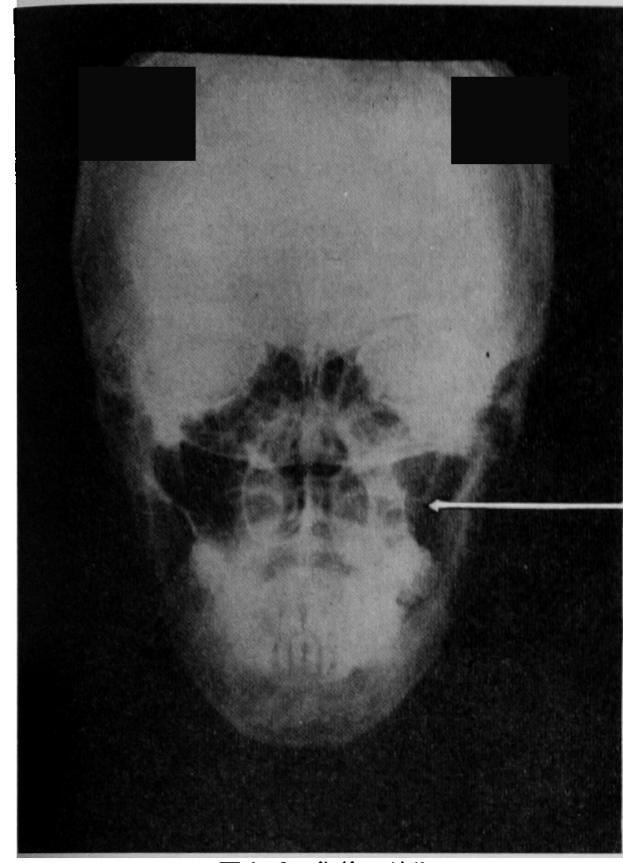

写真 8 術後X線像

a 、㛲骨は完全に整得されている，上䅡洞のX楾透過性は正 革である

ないるのに適応させる，これに対して，側頭経由法は， おすに頉骨弓の変位の強い場合に用いられる.

head cap を用いる方法は，頓骨体に金属線，あるい はフックをかけて整復したり，煩骨体に pinを立 てて，これにより整復固定する方法であるが整復方向や， その程度を調節出来ない欠点がある.

上頻洞䅅由法は，上額洞内に曲針を㨀入して，陥没し ‘颗骨を整復し，タンボンを挿入し，固定するもので， 鼻腔と犬菊窩からのアプローチがある，以上は、いずれ 的新鮮例に適応される方法である.

open reduction は眼窝上外側および，下眼瞼部を切 開して，骨折部を露出して，整復固定を行ならもので, 告も火陳旧性骨折に用いられる。

私達が稆介した balloon method は, 上顎洞経由法の 一型で，曲針で整復しタンポンで固定するかわりに，上 頻洞に留置カテーテルを挿入して，先端の balloon を膨 らませることにより整復と固定を同時に行なら方法であ る.曲針を㨀入して煩骨を整復しタンポンでそれを固定 ナるためには，上類洞を大きく開空する必要があるばか りでなく，感染の危険が高いことを考えると， balloon method はきわめてすぐれた方法といえる。

balloon method Kは, Anthony') (1952) Б，およ び Jackson ${ }^{7)}$ (1956) の程鼻法と，Jarabak ${ }^{4}$ (1959) ら の経口法とがあり，それぞれの特徴がある．Gutman ${ }^{2)}$ は，Jarabak4)の方法は良好な結果は得られるが，口腔
チューブは罡芹にとってわずらわしいばかりでなく，チ

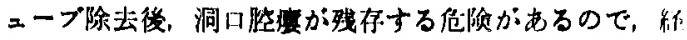

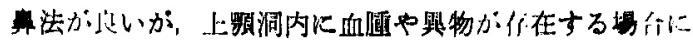
は，本法は健用出米ないと班べている。

私造は，これらの長所を取り入れ，カテーテルハルー

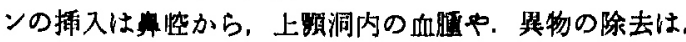
口腔内切開から行なっている。主たこの方法では， balloon 考胿腿させて整便を行なら愿に，骨片の適合状 態を直視しながら調節出来るといら利点がある。

さらに私達の用いている留居カテーテルは、 ハルーソ チューブの他にドレーチューブがくみこまれているので. 洞内のドレナージす周挂に行なえるので，術後の浮腄す 少なく，創伤治虑す速やかである，カテテーテルは， ： ルーン用量 $15 \sim 30 \mathrm{ml}, 30 \sim 45 \mathrm{ml}, 45 \sim 60 \mathrm{ml}$ のbのか あり，上䫂洞の大きさに応じて使い分ける（写而 9，10）.

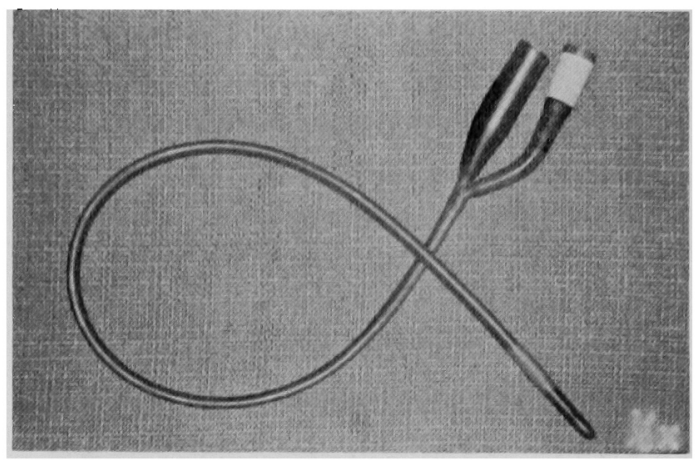

军真 9 留要カテーテル(導尿用)

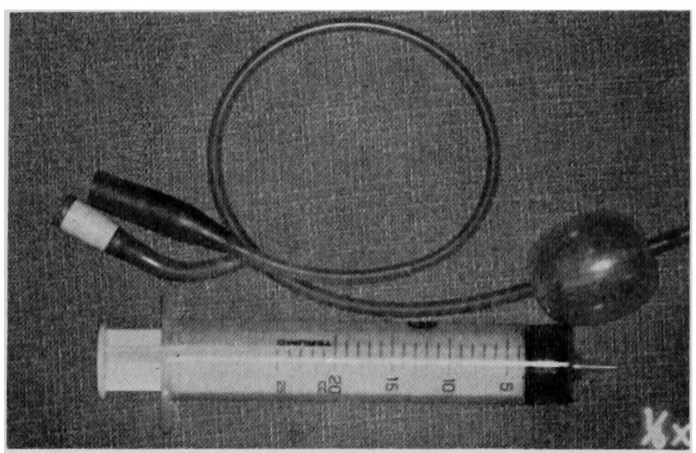

写真 10 留置カテーテル

先端のパルーンに空気を注入したところ

以上のごとく, balloon method は，1）顔面に傷をつ けない，2）術式が簡便である，3）整復後ハルーンがそ のまま固定装置として働くので骨槰合やタンポナーデな どが省略出来る．4）上顎洞内からの渗出液を持続吸引 出来るので，術後の浮腫が少ないなどの利点がある．

しかし，一方整復力が弱いので，1）覀陳旧性骨折や 陳旧性骨折には利用出来ない，2）上顎洞炎のあるるの 
には使用出来ない，3）烦骨の上哿洞内份没情折以外飞

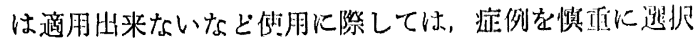
することが必要である。

\section{おわりに}

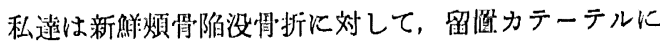
よる些復固定手術を行ない良好な絬果を得ている。本法 は症例を避択して用いれ湈きわ好すぐれた方法である と洘える。

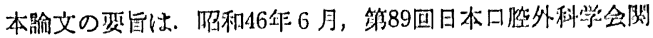
束地方会において㢸装した。

\section{文献}

1) Anthony, D. H. : Symposium, facial injuries, diagnosis and surgical treatment of the orbit. $\mathrm{Tr}$ Am Acad
Ophth $56: 5801952$.

2) Gutman, D., Laufer, D. \& Neder A. : The use of the Foly catheter in the treatment of zygomatic bone fractures. Brit J Oral Surg 2:153 1965.

3) Kazanjian, V.H. \& Converse J.M.: The surgical treatment of facial injuries. 2nd. The Williams \& Wilkins Co., 1959.

4) Jarabak, J.P.: Use of the Foley catheter in supporting zygomatic fractures. J Oral Surg $17: 391959$.

5) Rogeo, E. A. \& Canoll G. T. : Utilization of Foley catheter in midfacial fracture redustion. $O s \mathrm{Om}: \&$ Op $27: 4811970$.

6) Stamley, L. L. : The blow-out fractures. J Oral Surg $27: 5441969$.

7) Jackson, V.R. : Balloon technic for treatment of fractures of the zygomatic bone. J Oral Surg $14: 1956$.

8) Walter, W. C. : Treatment of zygomatic fracture-dislocation. J Oral Surg $17: 271959$. 